\title{
Comparison of LRINEC Scoring System with Finger Test and Histopathological Examination for Necrotizing Fasciitis
}

\author{
Farah Naaz Kazi, MBBS ${ }^{1} \quad$ J.V. Sharma, MS ${ }^{1}$ Shaurav Ghosh, MS ${ }^{1} \quad$ D. Prashanth, MS ${ }^{1}$ \\ V. Om Pramod Kumar Raja, MS ${ }^{1}$
}

${ }^{1}$ Department of General Surgery, Vydehi Institute of Medical Sciences and Research Centre, Bangalore, Karnataka, India

Address for correspondence J.V. Sharma, MS, Department of General Surgery, Vydehi Institute of Medical Sciences and Research Centre,

Surg J (NY) 2022;8:e1-e7. Bangalore, Karnataka, India (e-mail: jvpranavsharma@gmail.com).

\begin{abstract}
Keywords

- necrotizing fasciitis

- LRINEC

- Finger test

- histopathology

Background Necrotizing fasciitis (NF) is a life-threatening condition requiring urgent attention. It is clinically difficult to diagnose, linked to severe systemic toxicity, and has poor prognosis. In 2001, Andreasen and coworkers described the "Finger test" for the diagnosis of NF. Subsequent studies have suggested early recognition and management of NF. In this study, we compare the LRINEC-Laboratory Risk Indicator for Necrotizing Fasciitis-scoring system with the "Finger test" and histopathological examination for diagnosis of NF.

Results In our study, LRINEC scoring system and Finger test are statistically significant in the diagnosis of NF. Males are more frequently affected, and the most common organism causing NF is Staphylococcus. Histopathology remained the gold standard for diagnosis of NF, while LRINEC score and Finger test were good diagnostic tools for early diagnosis, with sensitivities of 83.33 and $86.11 \%$, respectively.

Conclusion LRINEC laboratory-based scoring system is easy and reliable diagnostic tool though histopathology remains the gold standard. There is statistically significant correlation between histopathology and laboratory criteria. LRINEC test is independently better than bedside Finger test alone or combined LRINEC and bedside Finger test.
\end{abstract}

Necrotizing fasciitis (NF) is a rapidly progressing fascial tissue inflammation and necrosis, with relative skin and underlying muscle sparing. A surgical emergency managed by patient optimization is the key to achieve high quality post operative results.

There is a stark difference between inflamed tissue and necrotized tissue. Inflamed tissue is the damaged tissue in response to the microorganism or injury, which leads to an increased blood supply and permeability of blood vessels, while necrotized tissue consists of dead and decaying group of cells caused by infection, trauma, or toxins, which in turn delays the healing of the tissues.

received

June 28, 2021

accepted after revision

October 15, 2021
The average annual incidence of NF for every 100,000 inhabitants was $0.86{ }^{1}$ With respect to all age groups, the incidence of NF spiked to 2.5 times more for men across all age groups. ${ }^{1}$ Among the comorbid patients, diabetic individuals were found to be more affected. Clostridium infections also are major causative factor. Delay in surgical intervention can be fatal. Another pitfall in diagnosis of NF is that even patients with mild pain, absence of fever, and crepitus can have soft tissue infection. Diagnostic tools used in determining NF are Laboratory Risk Indicator for Necrotizing Fasciitis (LRINEC) scoring system, Finger test, histopathology tissue

(C) 2022. The Author(s).

This is an open access article published by Thieme under the terms of the Creative Commons Attribution License, permitting unrestricted use, distribution, and reproduction so long as the original work is properly cited. (https://creativecommons.org/licenses/by/4.0/)

Thieme Medical Publishers, Inc., 333 Seventh Avenue, 18th Floor, New York, NY 10001, USA 
culture, and radiological investigations. LRINEC scoring system is a sum total of C-reactive protein (CRP) test, total count, serum sodium, serum creatinine, and blood glucose levels. ${ }^{2}$ Positive and negative predictive values of $92 \%$ and $96 \%$, respectively, are found when the LRINEC score is 6 or more. A value of $<5$ is considered low risk, 6 to 7 is considered of intermediate risk, while $>8$ is considered high risk. In case of ambiguity regarding diagnosis, Finger test was done, which was proposed by Andreasen et al. ${ }^{3}$ Pointers of NF are lack of bleeding, appearance of malodorous dish water pus, and lack of finger dissection resistance. ${ }^{2}$

Stamenkovic and Lew ${ }^{4}$ showed that early frozen tissue biopsy can provide a conclusive and life-saving diagnosis in a case of suspected NF. McHenry et $\mathrm{al}^{5}$ showed that early necrotizing soft tissue injury (NSTI) debridement was linked to a large mortality decline. Bilton et $\mathrm{al}^{6}$ showed that vigorous and immediate operative intervention of NF decreased the number of deaths.

Aim: Comparative study between LRINEC scoring system, Finger test, and histopathology for discerning NF from other soft tissue infections.

\section{Materials and Methodology}

\section{Source of Data}

All patients admitted to the General Surgery Outpatient Department of a tertiary care hospital in Bangalore were considered. Sample sizes of 40 patients were taken. Study duration of 18 months, with a follow-up period of 6 months, was considered.

\section{Inclusion Criteria}

Patients clinically diagnosed with NF, belonging to the age group of 18 to 90 years of either gender were included.

\section{Exclusion Criteria}

Patients previously diagnosed with NF were not considered. Patients on steroid treatment or with deep vein thrombosis, abscess, erysipelas, lymphedema, peripheral vascular disease, ischemic heart disease, and cerebrovascular accidents were excluded. Only patients willing to consent to the study were included. Patients not having enough background investigations, hence LRINEC score cannot be calculated, and patients who have already participated in the study and have come for a follow-up were also excluded.

\section{Study Design}

An observational study.

\section{Methods and Data Collection}

Clinical evaluations and investigations involving 40 patients diagnosed with soft tissue infections. LRINEC tests, Finger test, and histopathology examinations were done. Data were collected and statistical analysis done. With regard to statistical methods, descriptive and inferential statistical analysis was executed in the current research. Mean \pm standard deviation (SD; Min-Max) represented the continuous measurements while the number (\%) represented the categorical measurements. A 5\% level of significance was used to evaluate the significance. Fisher's exact test/chi-squared test was used to discover the relevance of research parameters on categorical scale between two or more groups. Qualitative data analysis used the nonparametric setting. For the small cell samples, the Fisher's exact test was worked with. Suggestive significance had a $p$-value between 0.05 and 0.10 , moderately significant had a $p$-value between 0.01 and 0.05 , while for strongly significant, the $p$-value was $\leq 0.01$.

To calculate the specificity and sensitivity of the criteria, data were distributed according to the outcome of the diagnosis. Sensitivity measures the proportion of actual positives that are correctly identified as such, that is, the percentage of study group that was correctly identified to have NF. Specificity measures the proportion of actual negatives that are correctly identified as such, that is, the percentage of study group that was correctly identified to not have NF.

The ethics approval was obtained from Sri Manakula Vinayagar Medical College and Hospital, Pondicherry, while the data compilation was done in Vydehi Institute of Medical Sciences and Research Centre, Bangalore.

\section{Results}

Comparison of various parameters of LRINEC score in - Table 1 suggests that patients were in age $57.05 \pm 13.64(\mathrm{SD})$ with

Table 1 Comparison of clinical variables according to LRINEC results

\begin{tabular}{|c|c|c|c|c|}
\hline \multirow[t]{2}{*}{ Variables } & \multicolumn{2}{|l|}{ LRINEC result } & \multirow[t]{2}{*}{ Total } & \multirow[t]{2}{*}{$p$-Value } \\
\hline & Negative & Positive & & \\
\hline Age & $60.22 \pm 13.89$ & $56.12 \pm 13.66$ & $57.05 \pm 13.64$ & 0.435 \\
\hline $\mathrm{HB}(\mathrm{g} / \mathrm{dL})$ & $11.15 \pm 2.61$ & $10.33 \pm 2.07$ & $10.52 \pm 2.19$ & 0.333 \\
\hline TLC (/cu.mm) & $14,900.00 \pm 6,523.80$ & $20,577.41 \pm 67,985.90$ & $19,300.00 \pm 7,065.19$ & $0.032^{*}$ \\
\hline Serum creatinine (micmol/L) & $86.66 \pm 20.00$ & $207.41 \pm 146.85$ & $180.25 \pm 138.85$ & $0.020^{*}$ \\
\hline Serum sodium (mmol/L) & $138.11 \pm 4.85$ & $134.09 \pm 5.50$ & $135.00 \pm 5.57$ & $0.056+$ \\
\hline Serum glucose (mmol/L) & $9.33 \pm 3.66$ & $14.76 \pm 9.72$ & $13.54 \pm 8.98$ & 0.111 \\
\hline C-reactive protein (mg/L) & $97.55 \pm 20.70$ & $181.29 \pm 31.91$ & $162.45 \pm 46.10$ & $<0.001^{* *}$ \\
\hline
\end{tabular}

Abbreviations: HB, hemoglobin; LRINEC, laboratory risk indicator for necrotizing fasciitis; TLC, total leukocyte count.

*Significant values. 
Table 2 Finger test and histopathology distribution in relation to LRINEC results in patients studied

\begin{tabular}{|l|l|l|l|}
\hline \multirow{2}{*}{ Bedside Finger test } & \multicolumn{2}{|l|}{ LRINEC result } & \multirow{2}{*}{ Total } \\
\cline { 2 - 3 } & Negative & Positive & \\
\hline Negative & $3(33.3 \%)$ & $3(9.7 \%)$ & $6(15 \%)$ \\
\hline Positive & $6(66.7 \%)$ & $28(90.3 \%)$ & $34(85 \%)$ \\
\hline Total & $9(100 \%)$ & $31(100 \%)$ & $40(100 \%)$ \\
\hline Histopathology & \multicolumn{2}{|l|}{ LRINEC result } & \multirow{2}{*}{ Total } \\
\cline { 2 - 3 } & Negative & Positive & \\
\hline Necrotized tissues & $6(66.7 \%)$ & $30(96.8 \%)$ & $36(90 \%)$ \\
\hline Inflamed tissue & $3(33.3 \%)$ & $1(3.2 \%)$ & $4(10 \%)$ \\
\hline Total & $9(100 \%)$ & $31(100 \%)$ & $40(100 \%)$ \\
\hline
\end{tabular}

Abbreviation: LRINEC, laboratory risk indicator for necrotizing fasciitis.

$p=0.435$, insignificant. Hemoglobin $(\mathrm{g} / \mathrm{dL})$ was $10.52 \pm 2.19$ (SD) with $p=0.33$, insignificant. Total leukocyte count (TLC) was around $19,300 \pm 7,065.19$ (SD) with $p=0.032$. Serum creatinine was $180.25 \pm 138.85$ (SD) with $p=0.020$, significant. Serum sodium was $135 \pm 5.57$ (SD) with $p=0.056$, significant. Serum glucose was $13.54 \pm 8.98$ (SD) with $p=0.111$, insignificant. CRP was $162.45 \pm 46.10$ (SD) with $p<0.001$, very highly significant.

In - Table 2, total 40 patients (100\%) were considered. Finger test and LRINEC results were both positive in 28 patients (90.3\%). Positive predictive value (PPV) $=90.32$ with sensitivity $=82.35$, specificity $=50.00, p$-value $=0.080$ + , and accuracy $=77.50$. Also, considering histopathology tissue culture and LRINEC results, 30 patients (96.8\%) were positive. Total $36(90 \%)$ patients confirmed necrotized tissue, remaining 4 (10\%) confirmed inflamed tissue. $P P V=96.77$, sensitivity $=83.33, \quad$ specificity $=75.00, \quad p$-value $=0.008^{* *}$, and accuracy $=82.58$.

\section{Chi-Squared Test/Fisher's Exact Test}

In -Table 3, the most common microorganism isolated comparing pus culture and sensitivity and LRINEC results is Staphylococcus. Total 15 (37.55\%) out of 40 patients were diagnosed positive for the same. Of these, 1 (11.1\%) was LRINEC negative and 14 (45.2\%) were LRINEC positive; $p=0.117$, insignificant. Streptococcus was detected in total of nine $(22.5 \%)$ patients. Of these, five (55.6\%) were LRINEC negative and four (12.9\%) were positive; $p=0.016$, significant.

Also, comparing pus culture and sensitivity with histopathology tissue culture results, it has showed Staphylococcus in $15(37.5 \%)$ out of 40 patients; $p=0.278$, insignificant. Streptococcus was detected in 9 (22.5\%) of 40 patients.

\section{Chi-Squared Test/Fisher's Exact Test}

In - Table 4, age and gender distribution in relation to LRINEC results showed the following. Of 15 patients (37.5\%) considered, the positive 13 patients (41.9\%) belonged to 61 to 70 years age group. Majority of the patients positive for LRINEC were male (80.6\%). Also majority of patients positive for histopathology were males (77.8\%).

In - Table 5, comparing bedside Finger test and histopathology, out of total 34 patients $(85 \%, n=100), 31$ patients (86.1\%) were positive for both bedside Finger test and histopathology findings: $p=0.554$, insignificant; PPV $=91.18$; sensitivity $=86.11$, specificity $=25.00$; and accura$\mathrm{cy}=80.00$. Also, comparing LRINEC results with histopathology, out of total 31 patients $(77.5 \%, n=100), 30$ patients (83.3\%) were positive for both LRINEC results and histopathology findings: $p=0.008^{* *}$, significant; $P P V=96.77$; sensitivity $=83.33$; specificity $=75.00$; and accuracy $=82.58$.

\section{Chi-Squared Test/Fisher's Exact Test}

- Table 6 presents association of LRINEC results with histopathology findings and LRINEC results. Of the 31patients (100\%), 28 (90.3\%) were positive for both: $p=0.024$. Studies of LRINEC results showed that out of 34 patients (100\%), 28

Table 3 Pus C/S distribution in relation to LRINEC and histopathology results in patients studied

\begin{tabular}{|c|c|c|c|c|c|c|c|c|}
\hline \multirow[t]{2}{*}{ Pus $\mathrm{C} / \mathrm{S}$} & \multicolumn{2}{|c|}{ LRINEC result } & \multirow{2}{*}{$\begin{array}{l}\text { Total } \\
(n=40)\end{array}$} & \multirow[t]{2}{*}{ p-Value } & \multicolumn{2}{|c|}{ Histopathology } & \multirow{2}{*}{$\begin{array}{l}\text { Total } \\
(n=40)\end{array}$} & \multirow[t]{2}{*}{$p$-Value } \\
\hline & $\begin{array}{l}\text { Negative } \\
(n=9)\end{array}$ & $\begin{array}{l}\text { Positive } \\
(n=31)\end{array}$ & & & $\begin{array}{l}\text { Inflamed } \\
\text { tissue } \\
(n=4)\end{array}$ & $\begin{array}{l}\text { Necrotized } \\
\text { tissues } \\
(n=36)\end{array}$ & & \\
\hline Acinetobacter & $0(0 \%)$ & $2(6.5 \%)$ & $2(5 \%)$ & 1.000 & $0(0 \%)$ & $2(5.6 \%)$ & $2(5 \%)$ & 1.000 \\
\hline Diphtheroid commensals & $0(0 \%)$ & $1(3.2 \%)$ & $1(2.5 \%)$ & 1.000 & $0(0 \%)$ & $1(2.8 \%)$ & $1(2.5 \%)$ & 1.000 \\
\hline Escherichia coli & $1(11.1 \%)$ & $5(16.1 \%)$ & $6(15 \%)$ & 1.000 & $0(0 \%)$ & $6(16.7 \%)$ & $6(15 \%)$ & 1.000 \\
\hline $\begin{array}{l}\text { Methicillin-resistant } \\
\text { Staphylococcus aureus }\end{array}$ & $1(11.1 \%)$ & $0(0 \%)$ & $1(2.5 \%)$ & 0.225 & $1(25 \%)$ & $0(0 \%)$ & $1(2.5 \%)$ & 0.100 \\
\hline Proteus mirabilis & $1(11.1 \%)$ & $2(6.5 \%)$ & $3(7.5 \%)$ & 0.545 & $0(0 \%)$ & $3(8.3 \%)$ & $3(7.5 \%)$ & 1.000 \\
\hline Pseudomonas aeruginosa & $0(0 \%)$ & $3(9.7 \%)$ & $3(7.5 \%)$ & 1.000 & 1 (25\%) & $2(5.6 \%)$ & $3(7.5 \%)$ & 0.277 \\
\hline Staphylococcus & $1(11.1 \%)$ & $14(45.2 \%)$ & $15(37.5 \%)$ & 0.117 & $0(0 \%)$ & $15(41.7 \%)$ & $15(37.5 \%)$ & 0.278 \\
\hline Streptococcus & $5(55.6 \%)$ & $4(12.9 \%)$ & $9(22.5 \%)$ & $0.016^{*}$ & $2(50 \%)$ & $7(19.4 \%)$ & $9(22.5 \%)$ & 0.213 \\
\hline
\end{tabular}

Abbreviations: C/S, culture and sensitivity; LRINEC, laboratory risk indicator for necrotizing fasciitis. 
Comparison of LRINEC Scoring System with Finger Test and Histopathological Examination for Necrotizing

Table 4 Frequency distribution of age and gender distribution in relation to LRINEC and histopathology results in patients studied

\begin{tabular}{|c|c|c|c|c|c|c|c|c|}
\hline \multirow[t]{2}{*}{ Variables } & \multicolumn{2}{|c|}{ LRINEC result } & \multirow[t]{2}{*}{ Total } & \multirow[t]{2}{*}{ p-Value } & \multicolumn{2}{|l|}{ Histopathology } & \multirow[t]{2}{*}{ Total } & \multirow[t]{2}{*}{$p$-Value } \\
\hline & Negative & Positive & & & Inflamed tissue & Necrotized tissues & & \\
\hline \multicolumn{9}{|l|}{ Age } \\
\hline$\leq 40$ & $0(0 \%)$ & $4(12.9 \%)$ & $4(10 \%)$ & \multirow[t]{5}{*}{0.247} & $0(0 \%)$ & $4(11.1 \%)$ & $4(10 \%)$ & \multirow[t]{5}{*}{0.658} \\
\hline $41-50$ & $3(33.3 \%)$ & $6(19.4 \%)$ & $9(22.5 \%)$ & & $2(50 \%)$ & $7(19.4 \%)$ & $9(22.5 \%)$ & \\
\hline $51-60$ & $2(22.2 \%)$ & 7 (22.6\%) & 9 (22.5\%) & & $0(0 \%)$ & $9(25 \%)$ & $9(22.5 \%)$ & \\
\hline $61-70$ & $2(22.2 \%)$ & $13(41.9 \%)$ & $15(37.5 \%)$ & & $2(50 \%)$ & $13(36.1 \%)$ & 15 (37.5\%) & \\
\hline$>70$ & $2(22.2 \%)$ & $1(3.2 \%)$ & $3(7.5 \%)$ & & $0(0 \%)$ & $3(8.3 \%)$ & $3(7.5 \%)$ & \\
\hline \multicolumn{9}{|l|}{ Gender } \\
\hline Female & $2(22.2 \%)$ & $6(19.4 \%)$ & $8(20 \%)$ & \multirow[t]{2}{*}{1.000} & $0(0 \%)$ & $8(22.2 \%)$ & $8(20 \%)$ & \multirow[t]{2}{*}{0.566} \\
\hline Male & 7 (77.8\%) & $25(80.6 \%)$ & $32(80 \%)$ & & $4(100 \%)$ & $28(77.8 \%)$ & $32(80 \%)$ & \\
\hline Total & $9(100 \%)$ & $31(100 \%)$ & $40(100 \%)$ & & $4(100 \%)$ & $36(100 \%)$ & $40(100 \%)$ & \\
\hline
\end{tabular}

Abbreviation: LRINEC, laboratory risk indicator for necrotizing fasciitis.

Table 5 Association of Finger test and LRINEC results in association with histopathology findings

\begin{tabular}{|l|l|l|l|}
\hline \multirow{2}{*}{$\begin{array}{l}\text { Bedside } \\
\text { Finger test }\end{array}$} & \multicolumn{2}{|l|}{ Histopathology } & \multirow{2}{*}{ Total } \\
\cline { 2 - 3 } & $\begin{array}{l}\text { Inflamed } \\
\text { tissue }\end{array}$ & $\begin{array}{l}\text { Necrotized } \\
\text { tissues }\end{array}$ & \\
\hline Negative & $1(25 \%)$ & $5(13.9 \%)$ & $6(15 \%)$ \\
\hline Positive & $3(75 \%)$ & $31(86.1 \%)$ & $34(85 \%)$ \\
\hline Total & $4(100 \%)$ & $36(100 \%)$ & $40(100 \%)$ \\
\hline \multirow{2}{*}{$\begin{array}{l}\text { LRINEC } \\
\text { result }\end{array}$} & Histopathology & \multirow{2}{*}{ Total } \\
\cline { 2 - 3 } & $\begin{array}{l}\text { Inflamed } \\
\text { tissue }\end{array}$ & $\begin{array}{l}\text { Necrotized } \\
\text { tissues }\end{array}$ & \\
\hline Negative & $3(75 \%)$ & $6(16.7 \%)$ & $9(22.5 \%)$ \\
\hline Positive & $1(25 \%)$ & $30(83.3 \%)$ & $31(77.5 \%)$ \\
\hline Total & $4(100 \%)$ & $36(100 \%)$ & $40(100 \%)$ \\
\hline
\end{tabular}

Abbreviation: LRINEC, laboratory risk indicator for necrotizing fasciitis.

(82.4\%) were positive for LRINEC results with histopathology findings and LRINEC results: $p=0.115$. Hence association between the two.

In - Table 7, association of LRINEC + Finger test results with histopathology findings was studied. Of the 36 patients (100\%), 33 (91.7\%) were positive for histopathology findings and LRINEC + Finger test: $p=1.000$.

\section{Discussion}

McHenry et $\mathrm{al}^{5}$ reported that prompt and quick debridement correlated with significant decreased mortality. Streptococcus pyogenes infection was the most common cause of monomicrobial NSTI, but was not linked to increased deaths. In our study, the commonest microorganism isolated was Staphylococcus. Wong et $\mathrm{al}^{7}$ showed LRINEC score detected NF in its early clinical stages. The presence of NF in patients with LRINEC score of $\geq 6$ should be thoroughly assessed for. In our study, hematological changes ( - Table 3 ) in NF are consistent with any septic process. Severe anemia and systemic sepsis are not contraindications for surgery. Patient optimization decreases presurgical risk factors. Serum sodium (-Table 5) was significantly lower in patients diagnosed with NF. These results may characterize kidney dysfunction due to multiorgan infection damage and also hyponatremia due to fluid sequestration in serious soft tissue infections. An elevated glycemic gap was significantly independently associated with outcomes in diabetic NF patients (-Table $\mathbf{6}$ ). We also concluded ( - Table 7 ) that CRP and creatinine were higher in patients with NF suggesting (-Table 4) increased risk of morbidity in patients diagnosed with NF.

Taviloglu et $\mathrm{al}^{8}$ showed that patients of age more than 55 years with perineal localization were individual risk factors for idiopathic NF. Polymicrobial infections seem the most predominant $(82 \%)$ while the death rate was found to be $35 \%$ with predominance among women, and patients with malignant diseases and diabetes mellitus. Stevens and Bryant $^{9}$ showed that early diagnosis, surgical intervention, and appropriate antibiotic treatment reduce mortality and improve outcomes. In our study, elderly patients constitute a risk factor for higher incidence and morbidity (-Table $\mathbf{1}$ ). This increases with risk factors like renal failure or delayed surgical debridement. It is also related to progression of the disease and a more severe infection. Majority of NF patients in our research were males (-Table 2 ). Length of hospital stay and the number of deaths of NF are similar in both the genders.

Stevens et $\mathrm{al}^{10}$ recommended guidelines emphasizing clinical skills to diagnose skin and soft tissue infections promptly, detect pathogens, and deliver effective treatments at the earliest. Group A streptococci (S. pyogenes) cause severe invasive infections. Anaya and Dellinger ${ }^{11}$ showed that early and full surgical debridement along with antimicrobial treatment and close monitoring shall be the heart of the treatment. The 2004 LRINEC score was initially released based on routine parameters and provides a method to detect cases at an early stage. Golger et $\mathrm{al}^{12}$ showed that 
Table 6 Association of LRINEC results with the histopathology findings and LRINEC results

\begin{tabular}{|c|c|c|c|c|}
\hline \multirow[t]{2}{*}{ Histopathology } & \multicolumn{2}{|c|}{ Finger test } & \multirow[t]{2}{*}{ Total } & \multirow[t]{2}{*}{$p$-Value } \\
\hline & Negative & Positive & & \\
\hline \multicolumn{5}{|l|}{ Inflamed tissue } \\
\hline \multicolumn{5}{|l|}{ LRINEC result } \\
\hline - Negative & $0(0 \%)$ & $3(100 \%)$ & $3(75 \%)$ & \multirow[t]{3}{*}{0.250} \\
\hline - Positive & $1(100 \%)$ & $0(0 \%)$ & $1(25 \%)$ & \\
\hline > Total & $1(100 \%)$ & $3(100 \%)$ & $4(100 \%)$ & \\
\hline \multicolumn{5}{|c|}{ Necrotized tissues } \\
\hline \multicolumn{5}{|l|}{ LRINEC result } \\
\hline$>$ Negative & $3(60 \%)$ & $3(9.7 \%)$ & $6(16.7 \%)$ & \multirow[t]{3}{*}{$0.024^{*}$} \\
\hline - Positive & $2(40 \%)$ & $28(90.3 \%)$ & 30 (83.3\%) & \\
\hline > Total & $5(100 \%)$ & $31(100 \%)$ & $36(100 \%)$ & \\
\hline \multicolumn{5}{|l|}{ Total } \\
\hline \multicolumn{5}{|l|}{ LRINEC result } \\
\hline$>$ Negative & $3(50 \%)$ & $6(17.6 \%)$ & $9(22.5 \%)$ & \multirow[t]{3}{*}{0.115} \\
\hline - Positive & $3(50 \%)$ & $28(82.4 \%)$ & 31 (77.5\%) & \\
\hline > Total & $6(100 \%)$ & $34(100 \%)$ & 40 (100\%) & \\
\hline
\end{tabular}

Abbreviation: LRINEC, laboratory risk indicator for necrotizing fasciitis.

Table 7 Association of LRINEC + bedside Finger test results with histopathology findings

\begin{tabular}{|l|l|l|l|}
\hline \multirow{2}{*}{$\begin{array}{l}\text { LRINEC result }+ \\
\text { Finger test }\end{array}$} & \multicolumn{2}{|l|}{ Histopathology } & \multirow{2}{*}{ Total } \\
\cline { 2 - 3 } & $\begin{array}{l}\text { Inflamed } \\
\text { tissue }\end{array}$ & $\begin{array}{l}\text { Necrotized } \\
\text { tissues }\end{array}$ & \\
\hline Negative & 0 & $3(8.3 \%)$ & $3(7.5 \%)$ \\
\hline Positive & $4(100.0 \%)$ & $33(91.7 \%)$ & $37(92.5 \%)$ \\
\hline
\end{tabular}

Abbreviation: LRINEC, laboratory risk indicator for necrotizing fasciitis. $p=1.000$; Significant, Fisher's Exact Test.

age, streptococcal toxic shock syndrome, and immune status are important mortality determinants and may, shortly after admission, predict death from NF. In our study also, early diagnosis and aggressive treatment remain key to management and we concur to this.

Lee et $\mathrm{al}^{13}$ showed that glycopeptides can be used as an empirical therapy in patients with severe invasive NF caused by community-associated methicillin-resistant Staphylococcus aureus until the susceptibility results are available. Its prognosis along with surgical intervention was found to be excellent. Su et al $^{14}$ concluded that the LRINEC score is linked with the outcomes of patients with NSTI. The death rates and amputation are higher in patients with $\geq 6$ LRINEC score. Frazee et $\mathrm{al}^{15}$ concluded that pathologically defined NSTIs are present with a vast range of symptoms and early diagnosis is challenging. Hsiao et $\mathrm{al}^{16}$ showed that in patients with NF, the independent positive predictors of death rate are Vibrio and Aeromonas infection, cancer, hypotension, and band form white blood cell count greater than $10 \%$. On the other hand, Streptococcal and Staphylococcal infections are not predictors of death rate. Hemorrhagic bulla is an autonomous negative predictor of mortality. Cheung et $\mathrm{al}^{17}$ concluded that clinicians should have high index of suspicion for NF and should start empirical therapy with repeated clinical tests. High survival rates are observed when surgical intervention of first fasciotomy and radical debridement are done within 24 hours of appearance of the symptoms.

Puvanendran et $\mathrm{al}^{2}$ emphasized that safeguarding must be done while treating patients with erythema, pain, and fever to make sure that this life-threatening condition is not missed. Hsu et al $^{18}$ showed that clinicians should be warned to differentiate between NF infections with Vibrio vulnificus (contact with seawater or raw seafood) and Klebsiella pneumoniae (abrasions or chronic ulcers) in diabetic patients based on exposure history and hospital presentation. $V$. vulnificus infections are more infectious than K. pneumoniae infections during the early stage.

Misiakos et $\mathrm{al}^{19}$ showed that early and aggressive drainage and debridement remains mainstay of treatment. Bryant and Stevens (2015) showed the need for early aggressive management of $S$. pyogenes infection. ${ }^{20}$ Pasternack and Swartz ${ }^{21}$ showed that lack of early diagnosis led to increased morbidity and mortality apart from escalated cost of treatment.

Khamnuan et $\mathrm{al}^{22}$ showed that risk factors of mortality in patients with NF included being female, age $>60$ years, skin necrosis, pulse rate $>130 / \mathrm{min}$, systolic blood pressure $<90 \mathrm{~mm} \mathrm{Hg}$, having chronic heart disease, liver cirrhosis, and serum creatinine level $\geq 1.6 \mathrm{mg} / \mathrm{dL}$. Therefore, patients with the above must undergo a serious surveillance to prevent further complications. Shaikh et $\mathrm{al}^{23}$ concluded that although males have a tendency to develop NF, females 
may also be at a high risk as they can develop NF of the groin and abdominal wall.

Organ failure is one of the most common complications seen in males. NF continues to be challenging as the mortality rate fluctuates between 25 and $27 \%$ among both male and female.

Bechar et $\mathrm{al}^{24}$ concluded that LRINEC score is a useful tool for patients with NF. El-Menyar et $\mathrm{al}^{25}$ stated that the scoring system would identify potential patients with NF along with pointing out hospital outcomes. Misiakos et $\mathrm{al}^{26}$ showed that clinicians with a close watch for NF showed better survival rates. Latifi et $\mathrm{al}^{27}$ concluded that time to surgery is a significant independent predictor of length of hospital stay.

In our research, we discovered that the majority of patients with histologically proven NF had an LRINEC score of 6 or higher. Our findings also proved that a combination of LRINEC scoring, Finger test, and histopathology tissue culture seemed to be very effective in diagnosing NF. S. aureus is the most common organism cultured from pus cultures. Streptococcus was the second most commonly cultured organism. Among the various parameters in LRINEC, TLC, serum creatinine, and CRP proved to have significant $p$ values in our study.

\section{Limitations}

Considering the fact that NF is a rare disease, the study was limited only to a small sample of patients. Another major limitation was the inability to calculate all the parameters of LRINEC for all patients. Hence, to overcome this, patients were added from low-risk NF as well and extensive search was done on our patient database to collect all the values.

\section{Conclusion}

LRINEC laboratory-based scoring system is an easy and reliable diagnostic tool for diagnosis of NF, though histopathology remains the gold standard for the diagnosis. In our study, we also found a statistically significant correlation between histopathology and laboratory criteria, and that LRINEC test is independently better than Finger test alone or combined LRINEC and Finger test. Also, patients with concomitant diseases showed poor prognosis.

\section{Authors' Contribution}

All the authors have made substantial contribution to the literature review, data interpretation, and the preparing of the manuscript for submission.

\section{Data Availability Statement}

The ethics approval was obtained from Sri Manakula Vinayagar Medical College and Hospital, Pondicherry, while the data compilation was done in Vydehi Institute of Medical Sciences and Research Centre, Bangalore. All data generated or analyzed during this study are included in this article. Further enquiries can be directed to the corresponding author.
Funding sources

No funding sources have been used.

Conflict of interest

The authors have no conflicts of interest to declare.

\section{Acknowledgment}

The authors would like to thank K.P. Suresh for his generous help in preparing the statistics tables.

\section{References}

1 Choi HK, Seo GH, Han E. The incidence and seasonal variation of necrotizing fasciitis in Korea: a nationwide cross-sectional study. Clin Microbiol Infect 2020;26(08):1090.e1-1090.e6

2 Puvanendran R, Huey JC, Pasupathy S. Necrotizing fasciitis. Can Fam Physician 2009;55(10):981-987

3 Andreasen TJ, Green SD, Childers BJ. Massive infectious soft-tissue injury: diagnosis and management of necrotizing fasciitis and purpura fulminans. Plast Reconstr Surg 2001;107(04):1025-1035

4 Stamenkovic I, Lew PD. Early recognition of potentially fatal necrotizing fasciitis. The use of frozen-section biopsy. N Engl J Med 1984;310(26):1689-1693

5 McHenry CR, Piotrowski JJ, Petrinic D, Malangoni MA. Determinants of mortality for necrotizing soft-tissue infections. Ann Surg 1995;221(05):558-563, discussion 563-565

6 Bilton BD, Zibari GB, McMillan RW, Aultman DF, Dunn G, McDonald JC. Aggressive surgical management of necrotizing fasciitis serves to decrease mortality: a retrospective study. Am Surg 1998;64(05):397-400, discussion 400-401

7 Wong $\mathrm{CH}$, Khin LW, Heng KS, Tan KC, Low CO. The LRINEC (Laboratory Risk Indicator for Necrotizing Fasciitis) score: a tool for distinguishing necrotizing fasciitis from other soft tissue infections. Crit Care Med 2004;32(07):1535-1541

8 Taviloglu K, Cabioglu N, Cagatay A, et al. Idiopathic necrotizing fasciitis: risk factors and strategies for management. Am Surg 2005;71(04):315-320

9 Stevens DL, Bryant AE. Necrotizing soft-tissue infections. N Engl J Med 2017;377(23):2253-2265

10 Stevens DL, Bisno AL, Chambers HF, et al; Infectious Diseases Society of America. Practice guidelines for the diagnosis and management of skin and soft-tissue infections. [published correction appears in Clin Infect Dis. 2005 Dec 15;41(12):1830] [published correction appears in Clin Infect Dis. $2006 \mathrm{Apr}$ 15;42(8):1219. Dosage error in article text]Clin Infect Dis 2005; 41(10):1373-1406

11 Anaya DA, Dellinger EP. Necrotizing soft-tissue infection: diagnosis and management. Clin Infect Dis 2007;44(05):705-710

12 Golger A, Ching S, Goldsmith CH, Pennie RA, Bain JR. Mortality in patients with necrotizing fasciitis. Plast Reconstr Surg 2007;119 (06):1803-1807

13 Lee YT, Lin JC, Wang NC, Peng MY, Chang FY. Necrotizing fasciitis in a medical center in northern Taiwan: emergence of methicillinresistant Staphylococcus aureus in the community. J Microbiol Immunol Infect 2007;40(04):335-341

14 Su YC, Chen HW, Hong YC, Chen CT, Hsiao CT, Chen IC. Laboratory risk indicator for necrotizing fasciitis score and the outcomes. ANZ J Surg 2008;78(11):968-972

15 Frazee BW, Fee C, Lynn J, et al. Community-acquired necrotizing soft tissue infections: a review of 122 cases presenting to a single emergency department over 12 years. J Emerg Med 2008;34(02): 139-146

16 Hsiao CT, Weng HH, Yuan YD, Chen CT, Chen IC. Predictors of mortality in patients with necrotizing fasciitis. Am J Emerg Med 2008;26(02):170-175 
17 Cheung JP, Fung B, Tang WM, Ip WY. A review of necrotising fasciitis in the extremities. Hong Kong Med J 2009;15(01):44-52

18 Hsu JC, Shen SH, Yang TY, Chen PH, Huang KC, Tsai YH. Necrotizing fasciitis and sepsis caused by Vibrio vulnificus and Klebsiella pneumoniae in diabetic patients. Biomed J 2015;38(02): 136-142

19 Misiakos EP, Bagias G, Papadopoulos I, et al. Early diagnosis and surgical treatment for necrotizing fasciitis: a multicenter study. Front Surg 2017;4:5

20 Stevens DL, Bryant AE. Severe Group A Streptococcal Infections. 2016 Feb 10. In: Ferretti JJ, Stevens DL, Fischetti VA, editors. Streptococcus pyogenes : Basic Biology to Clinical Manifestations [Internet]. Oklahoma City (OK): University of Oklahoma Health Sciences Center; 2016. Accessed December 29, 2021 from: https://www.ncbi.nlm.nih.gov/books/NBK333425/

21 Pasternack MS, Swartz MN. Cellulitis, necrotising fasciitis, and subcutaneous tissue infections. In: Mandell GL, Bennett JE, Dolin R, eds. Mandell, Douglas, and Bennett's Principles and Practice of Infectious Diseases. Philadelphia, PA: Churchill Livingstone Elsevier; 2015:1:1195-216
22 Khamnuan P, Chongruksut W, Jearwattanakanok K, Patumanond J, Yodluangfun S, Tantraworasin A. Necrotizing fasciitis: risk factors of mortality. Risk Manag Healthc Policy 2015;8:1-7

23 Shaikh N, El-Menyar A, Mudali IN, Tabeb A, Al-Thani H. Clinical presentations and outcomes of necrotizing fasciitis in males and females over a 13-year period. Ann Med Surg (Lond) 2015;4(04):355-360

24 Bechar J, Sepehripour S, Hardwicke J, Filobbos G. Laboratory risk indicator for necrotising fasciitis (LRINEC) score for the assessment of early necrotising fasciitis: a systematic review of the literature. Ann R Coll Surg Engl 2017;99(05):341-346

25 El-Menyar A, Asim M, Mudali IN, Mekkodathil A, Latifi R, Al-Thani $\mathrm{H}$. The laboratory risk indicator for necrotizing fasciitis (LRINEC) scoring: the diagnostic and potential prognostic role. Scand J Trauma Resusc Emerg Med 2017;25(01):28

26 Misiakos EP, Bagias G, Patapis P, Sotiropoulos D, Kanavidis P, Machairas A. Current concepts in the management of necrotizing fasciitis. Front Surg 2014;1:36

27 Latifi R, Patel AS, Samson DJ, et al. The roles of early surgery and comorbid conditions on outcomes of severe necrotizing softtissue infections. Eur J Trauma Emerg Surg 2019;45(05):919-926 